\title{
COMMON STRAWBERRY INSECTS AND THEIR CONTROL
}

\author{
by \\ H. ANDISON
}

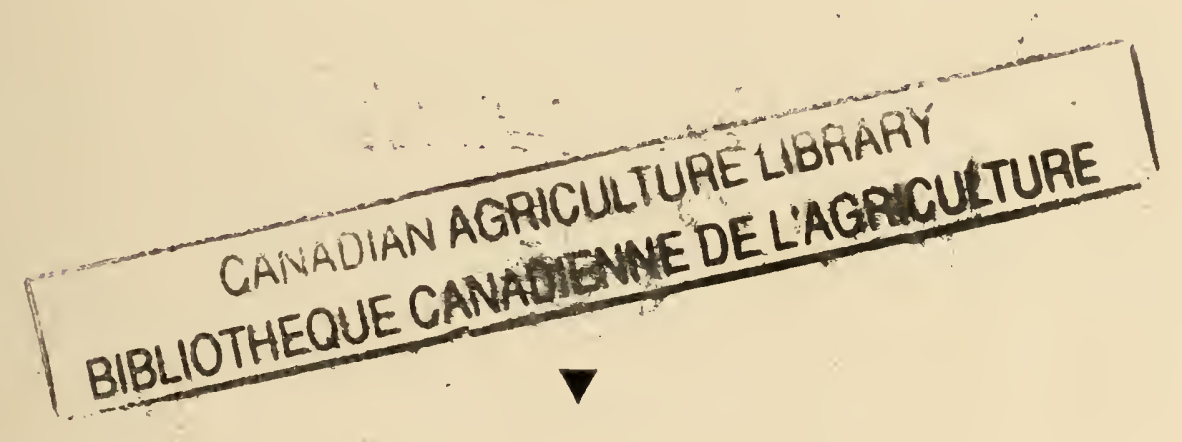

630.4

$\mathrm{C} 212$

P 990

1956

c. 3
SCIENCE SERVICE, ENTOMOLOGY DIVISION CANADA DEPARTMENT OF AGRICULTURE 12-12:56 
Digitized by the Internet Archive in 2012 with funding from

Agriculture and Agri-Food Canada - Agriculture et Agroalimentaire Canada 


\title{
COMMON STRAWBERRY INSECTS AND THEIR CONTROL
}

\author{
BY HARRY ANDISON \\ Entomology Laboratory, Victoria, British Columbia
}

In Canada strawberries are seriously attacked by comparatively few insects, and if the general practices given below are followed the necessity for control measures may often be avoided. It should be noted, however, that strawberry insect problems differ in various parts of the country, and that practices considered good in one locality may not be satisfactory or may have to be modified in another locality. For example, early spring burning of the plantation is widely practised in the Maritime Provinces to control the strawberry fruit bug and other pests but is not considered advisable in Ontario or British Columbia. Also, in certain areas of British Columbia the root weevils may require control measures every year, whereas in Ontario these are not necessary until an outbreak occurs. For these reasons only a general account can be given here and growers are urged to consult local agricultural authorities for further details.

\section{General Practices}

1. Set out only healthy plants.

2. Plant on land previously occupied by hoed crops that have been kept free from weeds. Avoid planting on land that was in sod the previous year.

3. Set new plantings as far as possible from old ones.

4. Keep the field free from weeds and grass and clean up any surrounding rough land; destroy wild brambles, raspberries, and thickets that may provide shelter for harmful insects.

\section{Key to Species Causing Damage}

The key given below is an aid to quick diagnosis of insect injury, but control measures should not be undertaken until the grower feels assured, from reading the full text, that the description fits his particular case. If in doubt send a sample of the insect and its damage to the Crop Insect Unit, Entomology Division, Canada Department of Agriculture, Science Service Bldg., Ottawa. Samples up to $12 \mathrm{oz}$. in weight may be sent through the mail free of postage.

Injury to Blossom Buds

Blossom stems cut, causing the buds to wilt, drop off, or hang by a

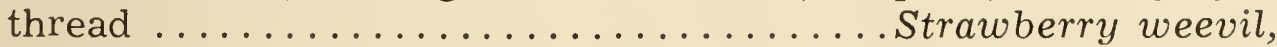

Injury to Fruit

Berries distorted or malformed, developing into so-called nubbins Meadow spittlebug, Strawberry fruit bug, Tarnished plant bug, 
Holes eaten in ripening fruit ........... Strawberry chlamys,

p. 19

Round holes eaten in ripe fruit ..........Strawberry root weevil,

p. 14

\section{Injury to Leaves}

Holes eaten in leaves by small, shiny beetles, giving the foliage a "shot holed" appearance .......... Strawberry leaf beetle,

p. 7

Leaves folded, usually along the midrib, by small greenish or brownish caterpillars that feed within the shelters thus formed Strawberry leaf roller,

Whitish or yellowish speckling on the foliage ....Spider mites,

p. 7

p. 9

Leaves chewed and plants defoliated by rose-colored grubs in black dome-shaped cases ................Strawberry chlamys,

White masses of spittle on leaf stems and other parts of plants Meadow spittlebug,

Leaves chewed during the night by smooth, stout caterpillars that hide under the soil by day .............. Cutworms,

Leaves in center of plant inrolled, crinkled, and deformed

Cyclamen mite,

p. 10

Notches eaten in edges of leaves .........Strawberry root weevil,

p. 14

Black vine weevil,

p. 17

Plants stunted, leaves and blossom trusses deformed .. Shallot aphid,

p. 20

Injury to Crowns

Small, pink caterpillars boring in crown

Strawberry crown miner,

p. 20

Larger, whitish caterpillars boring in crown

Strawberry crown moth,

p. 18

\section{Injury to Roots}

Large whitish grubs, with six distinct legs, eating the roots and killing the plants .......................... ghite grubs,

Large, whitish grubs, without legs, feeding on rootlets and weakening or killing the plants ............Strawberry root weevil, Black vine weevil,

p. 14

p. 17

Thin, shiny brown larvae feeding on roots ........ Wireworms,

p. 18

\section{Injury to Collar}

Plants cut off near ground level by smooth, stout caterpillars that hide under the soil by day .............. Cutworms, 

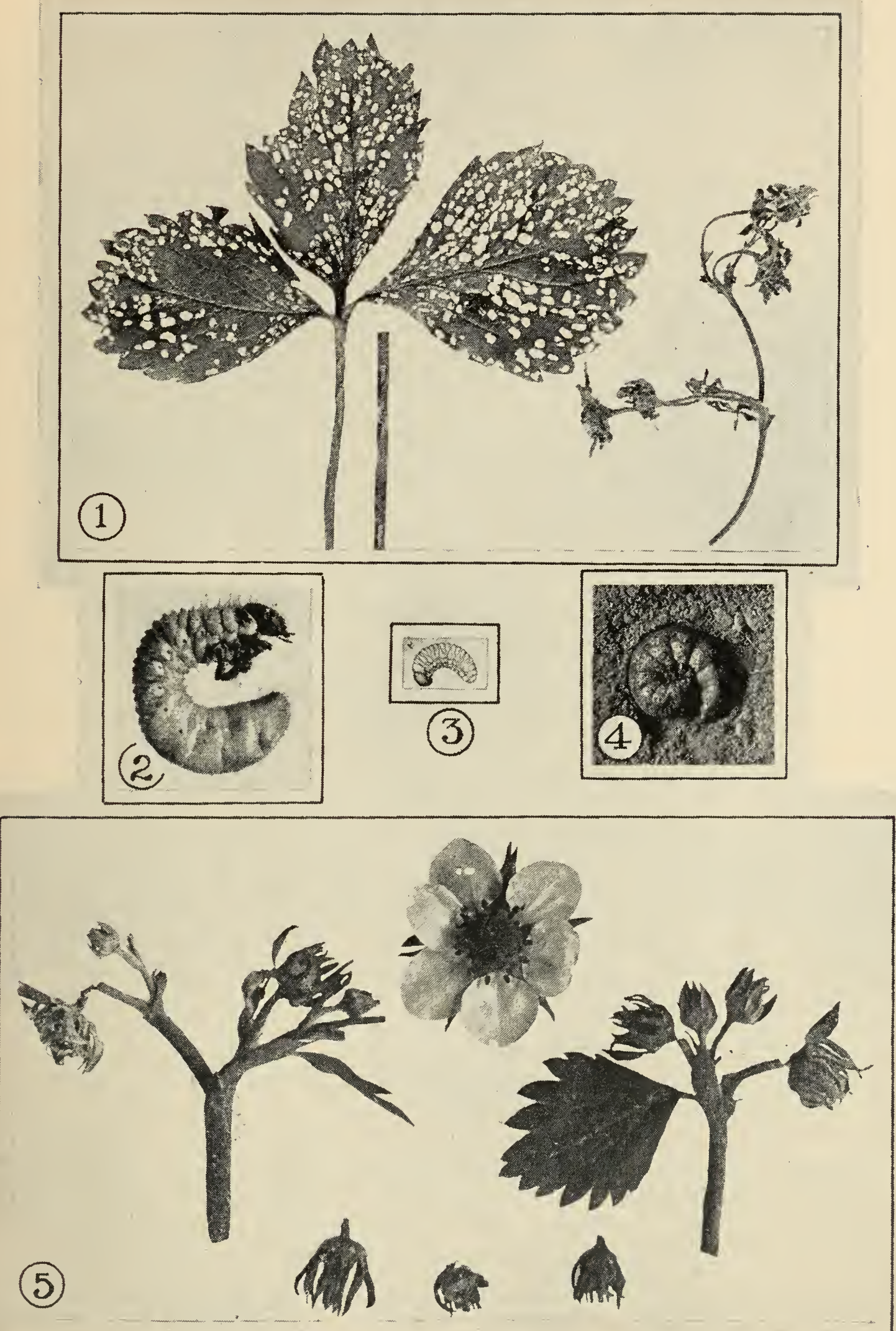

Figure 1.-1. Work of the strawberry leaf beetle. 2. White grub. 3. Strawberry root weevil. 4. Cutworm. 5. Work of the strawberry weevil. 


\section{Strawberry Weevil \\ Anthonomus signatus Say}

This insect, a very small, reddish brown or blackish snout beetle, approximately $\frac{1}{10}$ inch long, may very seriously reduce the crop by cutting off unopened blossom buds. Occasionally it attacks blackberry and raspberry.

The beetles begin to appear in the spring when the first few strawberry blossoms open. Their presence at this time is indicated by small round holes that they eat in the petals. The presence of these holes should warn the grower to keep a close watch on the plantation and to prepare for spraying or dusting the plants. The female weevil punctures the side of an unopened blossom bud and inserts an egg into the interior of the bud. She then crawls down the stem a short distance, girdles it, and leaves the bud hanging by a thread or severs the stem completely so that the bud falls to the ground (Fig. 1(5)). The egg hatches, the larva develops inside the bud, and a new beetle comes out in July about the time the crop has been harvested. There is but one generation a year, and the new beetles hibernate in the plantation itself and in brambles or hedgerows of wild and escaped raspberry canes that may be growing in the vicinity.

\section{Control}

As soon as bud-cutting begins, dust the plantation with a 3 per cent DDT dust. Apply the dust with a power duster or a good hand blower, preferably in the morning when the dew is going off and when there is little or no wind. DDT may also be used as a liquid spray applied as soon as the first blossom petals showing typical weevil injury are found. Use 50 per cent wettable DDT, $2 \mathrm{lb}$. in 100 gal. of water.

Injury from this insect may be reduced and sometimes prevented by clearing up all thickets, bushes, fence rows, and wild strawberries and raspberries near the strawberry plantation. Set out new plantings as far as possible from the old. The practice in the east of cleaning up old plantations by burning them over in the early spring affords little or no control of this insect.

\section{Strawberry Fruit Bug \\ Calocoris norvegicus (Gmelin)}

In Nova Scotia, and possibly elsewhere, this small, active, green bug frequently causes extensive damage to the developing fruit by sucking the juices from it. In severe cases the fruit may fail to develop, but in lighter infestations the berries may be distorted or malformed, developing into so-called nubbins. The bugs, in both the mature and immature stages, are very active and furtive and are not likely to be observed unless a careful search is made. For this reason the damage caused by this insect is usually attributed to some other agency such as frost or imperfect pollination.

Though a complete study of the life-history of this insect has not yet been made, observations indicate that the winter is passed in the egg stage. The eggs are deposited in the stems of the strawberry plants and also some weeds, including sheep sorrel, one of the insect's favored food plants. The young bugs appear in the spring soon after the first blossoms open and may begin stinging the fruit as soon as it starts to form. About the time the fruit is ripe the bugs are full-grown, and they soon leave the strawberries and may be found on a number of plants, including many field and garden crops, grasses, and weeds. 


\section{Control}

Spray with 50 per cent wettable DDT, $2 \mathrm{lb}$. in 100 gal. of water, when the first blossoms appear. Keeping the plantation free from weeds, especially sheep sorrel, will help in control.

\section{Tarnished Plant Bug \\ Lygus lineolaris (Beauv.)}

This common bug attacks many plants and in several provinces has caused damage to strawberries very similar to that of the strawberry fruit bug. The major damage is caused by the adults and nymphs sucking the juices from the developing buds and berries, resulting in a hard, malformed fruit that is unfit for sale.

The adults are brownish, flattened, oval in outline, and about $\frac{1}{4}$ inch long. They overwinter under leaves and debris and emerge in the spring to feed and lay their eggs on a great variety of plants. There are at least two generations each season.

\section{Control}

Plantations and their surroundings should be kept free of weeds. A spray of 50 per cent DDT, $2 \mathrm{lb}$. in 100 gal., when the first blossoms appear will give commercial control.

\section{Strawberry Leaf Beetle Paria canella (F.)}

In spring and autumn, strawberry plants are occasionally attacked by a dark-brown or black, shiny, oval-shaped beetle about $\frac{1}{8}$ inch long that eats holes in the leaves, giving them a lacework effect (Fig. 1(1)). This insect feeds also on raspberry, blackberry, greenhouse roses, and some other plants.

The beetles hibernate among old leaves, straw, or trash, and as soon as growth commences in the spring they feed voraciously on the leaves. Eggs are laid in the soil close to the crowns of the plants and on the undersides of dead leaves lying around the plants. The very small larvae that hatch from these eggs burrow into the soil and feed on the rootlets of the strawberry plants, where they may cause considerable injury when present in sufficient numbers. When full-grown the larvae are about $\frac{1}{6}$ inch long. They then pupate in the soil, and the new beetles emerge from about the end of July to September. After feeding for a while the beetles go into winter quarters.

Control

It is seldom necessary to spray for the control of this pest. If the beetles are very abundant they may be controlled by spraying thoroughly with either $5 \mathrm{lb}$. of lead arsenate or $3 \frac{3}{4} \mathrm{lb}$. of calcium arsenate, or $2 \mathrm{lb}$. of 50 per cent wettable DDT powder in 100 gal. of water. This spray should only be applied before blossoming, or after the crop has been picked. DDT may cause mites to become abundant.

\section{Strawberry Leaf Roller \\ Ancylis comptana fragariae (W. \& R.)}

Several species of leaf rollers with similar habits attack strawberries but the only one of economic importance is the strawberry leaf roller. The presence of leaf rollers can readily be detected by the folded leaves within which the larvae feed. 
The strawberry leaf roller winters in the larval stage in the folded leaves. In the spring the larvae pupate and transform to small, inconspicuous moths with a wing expanse of about $\frac{1}{2}$ inch. The eggs, which are not readily observed, are laid singly on the leaves. On hatching, the larvae feed on the leaves and soon begin to tie and fold them together. They feed within the shelters thus formed and are protected from most poison sprays. When full-grown the larvae are about $\frac{1}{2}$ inch long, very active when disturbed, and of a greenish or brownish color. The larvae pupate and change to moths in July and early August. These lay eggs for the second generation, the larvae of which feed from August until stopped by cold weather.

\section{Control}

The following practices help to reduce the numbers of leaf rollers and lessen the need for chemical control: As soon as the last crop has been harvested, plow the plants under; set new plantings as far as possible from old ones. Use uninfested plants or, when setting out the plants, pinch folded leaves to kill the larvae within. Mowing the planting after harvest helps to reduce leaf roller infestations.

A spray of $1 \frac{1}{2} 1 \mathrm{~b}$. of 15 per cent wettable parathion or of $2 \mathrm{lb}$. of 50 per cent wettable DDD (TDE) in 100 gallons of water, or a dust of 7 per cent DDD is effective if thoroughly applied. Two hundred gallons of spray or 25 1b. of dust are required per acre for each application. Parathion gives better control than DDD if many larvae have folded the leaves before the spray is applied. The treatments should be applied as follows in areas where the leaf roller has been troublesome:-

(a) New. plantings (non-bearing).-For the first brood apply two sprays or dusts 10 days apart, starting the first or second week in June. If these sprays are not applied, or if the infestation is very heavy, spray twice, 10 days apart, for the second brood, starting about August 15.

(b) Bearing Plantings.-As injury by the first generation is seldom serious on bearing plantings, spraying or dusting is not usually recommended. However, for heavy infestations, a spray of DDD applied just as the first blossoms open gives some protection. In order to protect bees, and to avoid spray residues, poisons should not be applied during the bloom and fruiting periods.

If the planting is to be kept for another season's crop, the second generation may be controlled by spraying or dusting about August 15 and again 10 days later.

\section{Cutworms}

Several species of cutworms may cause much damage in strawberry plantations by cutting off the new plants at ground level and by chewing the foliage of older plants. In general, most cutworms are similar in appearance, being smooth, cylindrical caterpillars about an inch long and of a dull earth color (Figure 1(4)). They feed during the night and hide in the soil during the day. Cutworms usually cease causing damage before the end of June. The adults are drab-colored moths that fly during the night and are often attracted to lights.

\section{Control}

The following poisoned bait controls cutworms:-

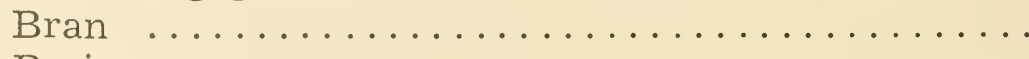

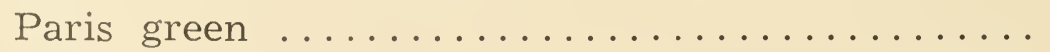

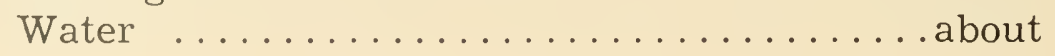

25 lb.

$1 \mathrm{lb}$.

$2 \frac{1}{2}$ gal. 
Mix the bran and poison; then add water slowly to this mixture while stirring. Scatter the bait thinly on the ground after sundown, along the rows where the cutworms are present. It is important that this should be done in the evening and only after a warm day. Fifteen pounds of bait will treat about an acre. Where cutworms are abundant, one baiting may not be sufficient. Proprietary baits containing apple waste are effective in controlling most species in British Columbia.

For a new planting that will not be cropped until the next year, a grower may prefer to spray or dust. Spray with 50 per cent wettable DDT, 2 lb. in 100 gal. of water, or dust with a 3 per cent DDT dust. It is essential to apply the control measures early in the spring to kill the immature caterpillars before they cause extensive damage.

In plots where cutworms are present, it is advisable to broadcast baits on a warm evening, or dust with DDT a few days before setting out the plants.

\section{Spider Mites}

Spider mites, commonly known as 'red spiders', are occasionally troublesome pests of strawberries. They are more likely to be abundant if DDT is applied early in the season. The two-spotted spider mite, Tetranychus bimaculatus Harvey, occurs in practically all strawberry-growing areas.

Mite injury is first apparent as very fine whitish or yellowish speckling on the foliage. This is caused by the mites sucking out the juices, giving the foliage a pale, unhealthy appearance. Later the leaves may turn brown and drop. The undersides of the leaves are covered with a fine silken web, beneath which the mites may be seen as tiny moving dots. Injury is usually most severe in hot, dry weather.

The adult mites are about $1 / 50$ inch long; during most of the season they are pale greenish yellow but in the fall or on badly injured foliage they may be orange-red. They overwinter under trash and in the soil about the bases of the plants. When growth starts in the spring they crawl up to the leaves and commence to lay eggs on the undersides. The mites that hatch from these eggs mature rapidly in warm, dry weather and in turn lay eggs that produce more mites. There may be as many as 10 generations a year in the warmer parts of Canada.

\section{Control}

If spider mites are easily found, or if the leaves show spotting from their feeding, spray with TEPP, Aramite, or Ovotran, diluted according to the manufacturer's directions. Do not use TEPP or Aramite with hydrated lime or bordeaux mixture. TEPP spray has to be repeated in 7 to 10 days, and the other materials may require a second application. A coarse, driving spray at high pressure gives the best coverage of the undersides of the leaves.

Aramite and malathion have been used successfully as sprays or dusts in British Columbia.

Non-bearing patches may be sprayed at any time. If it is necessary to control mites during harvest, pick the fruit closely, spray with TEPP, and do not pick for at least two days. Follow the same procedure for a second spray 7 to 10 days later. 


\section{Cyclamen Mite \\ Tarsonemus pallidus Banks}

This mite is not uncommon on strawberries in many sections of Canada but only occasionally causes sufficient damage to be noticed by the grower. On infested plants the unopened leaves turn yellowish, then brownish, and may die, or if they open they remain crinkled and deformed. The mites can scarcely be observed with the unaided eyes but can be found with a magnifying lens if the young, unopened leaves are unrolled so as to expose them. Since the symptoms are not clearly marked in the early stages, the presence of the mites is the only certain criterion.

The mites shun the light and prefer the seclusion of the folds of unopened leaves, where they feed and lay their eggs. As the leaves expand, the mites avoid exposure by moving to younger, unopened leaves. In these and the crowns they pass the winter, and begin feeding and reproducing the following spring.

\section{Control}

The only effective control measure known at the present time is to dip the young plants in hot water before they are set out in the spring. Experiments have shown that plants should be immersed in water at a temperature of $110^{\circ} \mathrm{F}$., but not higher, for 20 minutes. After this they should be quickly cooled by plunging them into a bath of cold water. To ensure control it is recommended that if the plants are tied into bundles (25-50) the strings should be cut before dipping; otherwise the temperature in the center of the bundle will fail to reach $110^{\circ} \mathrm{F}$., or will reach it so slowly that not all of the mites will be killed. It is most important that the temperature of the water be held at $110^{\circ}$ during the entire period of immersion, for if the temperature reaches $115^{\circ}$ the plants will be killed and if it falls to $107^{\circ}$ the mites will not be killed. A reliable and easily read thermometer should be used and the water kept stirred to ensure even temperature throughout. Plants should be set out as soon as possible after treatment. It is particularly important that stock plants sold to growers should be free from this mite.

\section{Meadow Spittlebug \\ Philøenus leucophthalmus (L.)}

This insect commonly attacks weeds and other plants but occasionally appears on strawberries in sufficient numbers to reduce the crop and weaken the plants. Injury is most marked when an infestation coincides with a dry season.

The eggs, the stage in which winter is passed, are probably laid on the leaves and stems of the plants. They begin to hatch about the time the earliest strawberry blossoms appear, and the young nymphs feed on the plants by piercing the tissue and sucking out the plant juices in much the same way as aphids. Very soon the nymphs are surrounded by drops of clear liquid and later by considerable amounts of white spittle. They are most commonly found on and between the flower-bud clusters when the latter are still compact, on leaf stems, and on the young growth of the crown. Each spittle mass may contain one or more nymphs. The nymphs develop into adults about the time the crop is harvested. The adults both fly and hop, are usually dull brown, and are about $\frac{1}{4}$ inch long. There is only one brood a year. 


\section{Control}

Once the spittle masses appear, the nymphs are well protected and control is difficult. Where it is known, from the previous year's experience, that an attack is likely to occur, the plantation should be sprayed, as soon as the earliest blossoms appear, with 50 per cent wettable DDT, 2 lb. in 100 gal. of water. Sufficient pressure must be used to drive the spray into the compact, young growth.

\section{White Grubs \\ Polyphylla perversa Csy. Phyllophaga spp.}

White grubs, the larvae of the well-known June beetles (or June 'bugs'), are the large, stout, grayish white grubs, usually curved in an almost complete circle when at rest, that are frequently found feeding on the roots of strawberries (Figure 2). They either kill or severely weaken the plants and are most destructive where strawberries are planted after sod. A striped June beetle, Polyphylla perversa Csy. (Figure 3), is confined to British Columbia and there are a number of species of Phyllophaga in Eastern Canada.
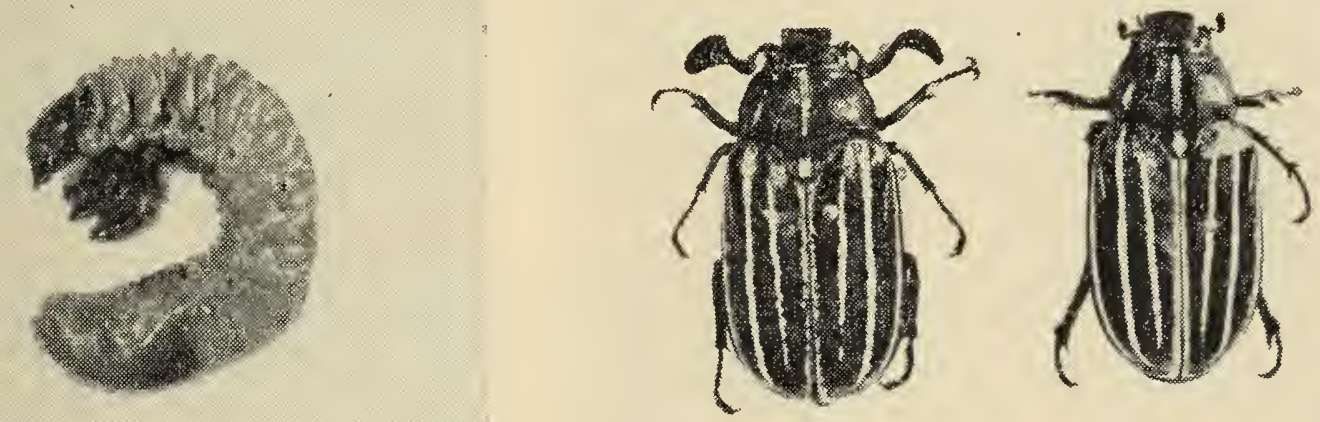

Figures 2 and 3.-The striped June beetle that commonly attacks strawberry in British Columbia. Male (left), female (center), and grub (right).

The white grubs that occur in the mid-west and Eastern Canada are usually destructive to strawberry only in Ontario and Quebec. They have a 3-year life-cycle and the adults occur in peak numbers in only one year out of three, their occurrence depending on the district. Most damage is done by the second-year grubs, and therefore serious injury may occur every third year.

The beetles of the eastern species appear in early summer and commonly fly about in the evening and at night, particularly about trees on the leaves of which they feed. They lay their eggs in soil covered with vegetation, chiefly on grass land. The eggs hatch and the tiny grubs feed on the roots of plants until late autumn, when they burrow deeper into the soil and remain dormant until the following spring. During their second summer they feed and again return to the deeper soil in the autumn to spend the winter. The third spring some of the grubs return to the roots near the surface for a short while before pupating and changing into beetles in late summer. Others remain in the subsoil and change into beetles in the autumn. The beetles do not leave the soil until the following spring. 
In British Columbia, the striped June beetle has a similar 3-year lifecycle but all stages are found in considerable numbers each year and injury may occur each year. Although damage by the second-year grubs is usually the most serious, third-year grubs do more feeding than the species occuring in the east.

\section{Control}

In British Columbia, during the past several years very satisfactory results have been obtained in field experiments in controlling white grubs in the soil. Four new and promising soil insecticides, aldrin, chlordane, dieldrin, and heptachlor, give good control under field conditions. These materials are available in Canada under various brand names. Where fields are known to be infested, apply one of these insecticides to the soil before plowing, and also dust the roots of the plants before planting.

1. Soil Treatments before Planting.-The amount of each formulation to use per acre to give the proper amount of actual insecticide is shown in the following table:-

\begin{tabular}{|c|c|c|c|c|}
\hline \multirow{2}{*}{ Formulation } & \multicolumn{4}{|c|}{ Amount per Acre } \\
\hline & $\begin{array}{l}\text { Aldrin } \\
5 \mathrm{lb} \text { (actual) }\end{array}$ & $\begin{array}{l}\text { Dieldrin } \\
4 \text { lb. (actual) }\end{array}$ & $\left|\begin{array}{c}\text { Chlordane } \\
10 \mathrm{lb} . \text { (actual) }\end{array}\right|$ & $\begin{array}{l}\text { Heptachlor } \\
4 \text { lb. (actual) }\end{array}$ \\
\hline $\begin{array}{r}\cdots \\
\cdots \\
5 \%\end{array}$ & $200 \mathrm{lb}$ & $\begin{array}{rl}160 & \mathrm{lb} . \\
80 & \end{array}$ & $20 \overline{\mathrm{lb}}$ & $\begin{aligned} 160 \mathrm{lb} . \\
80\end{aligned}$ \\
\hline $\begin{array}{r}\text { Wettable powder.................. } \\
50 \%\end{array}$ & $\begin{array}{ll}20 & \text { “ } \\
10 & \text { “ }\end{array}$ & $\begin{aligned} 16 & \text { “ } \\
8 & \text { “ }\end{aligned}$ & $\begin{array}{l}40 “ \\
20\end{array}$ & $\begin{aligned} 16 & \text { “ } \\
8 & \text { “ }\end{aligned}$ \\
\hline $\begin{array}{l}\text { Emulsifiable }) \ldots \ldots \ldots \ldots \ldots \ldots \ldots \ldots \ldots \ldots \ldots \ldots \ldots \ldots \ldots \ldots \ldots \ldots \ldots \ldots \ldots \\
\text { Concentrate) } \ldots \ldots \ldots \ldots \ldots \ldots\end{array}$ & $10 \mathrm{qt}$. & 2 gal. & $\overline{5 q t}$ & 2 gal. \\
\hline
\end{tabular}

Whatever material is used, distribute it evenly over the soil and immediately (1) work it in with a rotary cultivator or (2) plow it in to a depth of 6 to 8 inches, and then disk the land thoroughly. Where small plots are to be treated, use a small, hand-drawn fertilizer cart or spreader to apply the dusts (Figure 5). Where larger acreages are involved, use a large fertilizer or lime spreader that can be readily adjusted and pulled over the field by tractor (Figure 4). The insecticides may also be sprayed evenly over the soil before plowing (Figure 6). This method of application gives the most even distribution of the insecticide. Spray equipment for this type of application is described in Canada Department of Agriculture Processed Publication Series, Entomology, No. 119. By operating a rotary pump from the tractor power take-off and adjusting the spray boom to cover a 45-inch spray swath, you may obtain complete soil coverage. The spray boom should have six flat-type nozzles, each 9 inches apart and 6 inches above the soil surface. The nozzles should have disk apertures of 0.04 inch. By travelling at 2.5 m.p.h. and operating the pump at 100 pounds per square inch, you may apply approximately 200 gallons of spray per acre.

Results indicate that these materials are effective when applied at any time of the year, and they have not adversely affected the growth of strawberry plants. All four insecticides have a residual effect, each remaining toxic to white grubs for at least 3 years. No tainting of the fruit has resulted from the large-scale commercial use of these materials in British Columbia during the past 5 years. 
2. Plant Treatments before Planting.-Dust the roots of the plants before planting. Puncture the lid of a 20 -ounce jar or tin can with a 2-inch nail to make a "salt shaker" type of container for applying the dust to the roots. Use approximately 6 pounds of $2 \frac{1}{2}$ per cent aldrin, dieldrin, or heptachlor dust
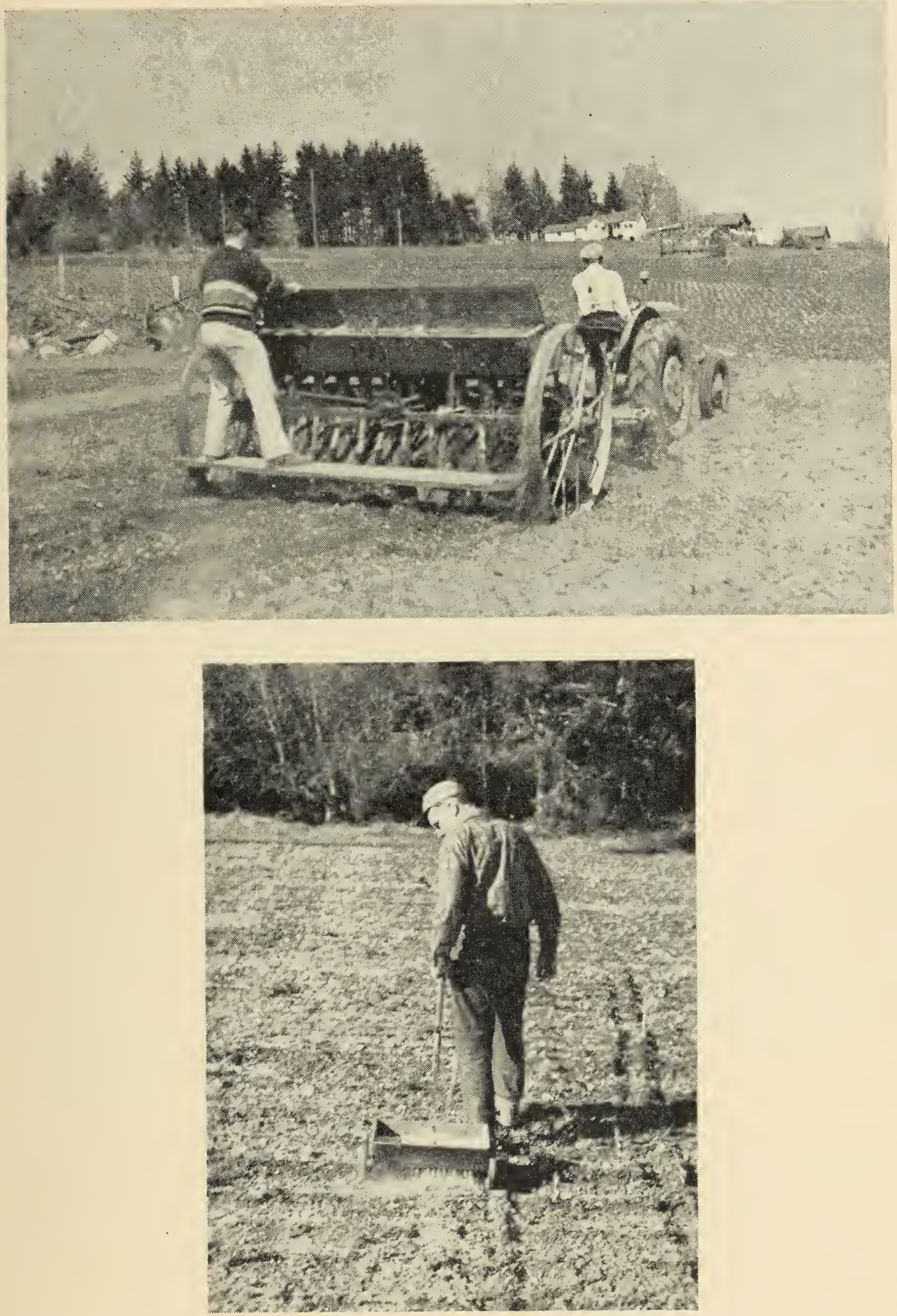

Figure 4 and 5-Combination drill for dusting large acreage and lawn-cart fertilizer spreader for small plantings. These may be used to apply insecticidal dusts to soil surface before plowing to a depth of 6 to 8 inches. To apply insecticides at 200 pounds per acre, adjust holes in bottom of fertilizer spreader to remain half-open. 
or 5 per cent chlordane dust per acre of strawberries, or 1 ounce per 100 plants. This treatment also gives immediate protection from root weevils and wireworms.

Recommendations for controlling white grubs in Eastern Canada are as follows: Do not plant strawberries on grub-infested soil or on land that was in sod the previous year. Frequent cross-disking before planting will reduce the number of grubs. Insecticides may be used before plants are set out in years when the destructive second-year grubs are present. Find out from your agricultural extension service which years these are. The amount of actual insecticide to use per acre is: (1) heptachlor, $3 \mathrm{lb}$. ( $2 \frac{1}{2}$ per cent dust at $120 \mathrm{lb}$. per acre); (2) aldrin, 3 to $5 \mathrm{lb}$. (2 $\frac{1}{2}$ per cent dust at 120 to $200 \mathrm{lb}$.

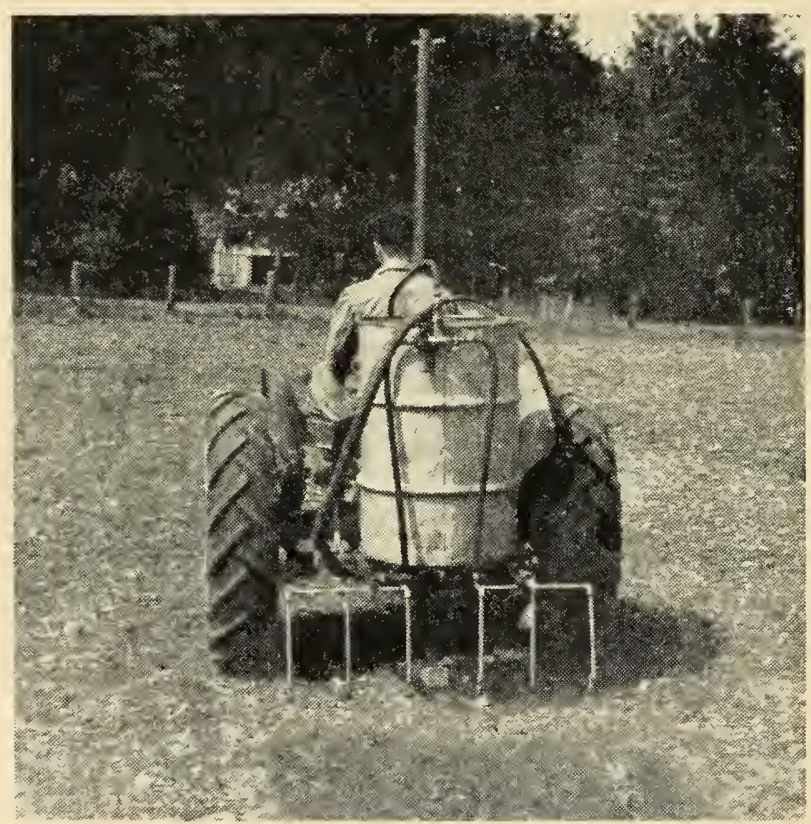

Figure 6.-Row-crop sprayer. This may be used to spray the surface of the soil with insecticide before plowing. The spray boom has 6 flat-type nozzles, each 9 inches apart and placed 6 inches above the soil level. The nozzles have disk apertures of 04 inch. Operating at 100 pounds per square inch and travelling at $2 \cdot 5 \mathrm{~m}$.p.h. the sprayer applies 200 gallons per acre.

per acre); or (3) chlordane, 5 to $10 \mathrm{lb}$. ( 5 per cent dust at 120 to $200 \mathrm{lb}$. per acre). The larger amounts are for heavy soils. They should be evenly distributed over the soil and immediately worked into the top 3 to 4 inches before planting. Granular dusts are preferred as they spread more readily. The materials may also be applied as sprays by adding the proper amount of a spray powder or emulsifiable formulation to a tank of water and spraying it evenly over the soil to give the right amount per acre.

\section{Strawberry Root Weevil}

Brachyrhinus ovatus (L.)

The strawberry root weevil, though widely distributed in Canada, ranks as a serious pest of strawberries chiefly in British Columbia, where it is most prevalent on light or sandy soils. The adult-a small, dark beetle (Figure 7), egg-shaped in general outline and about $\frac{1}{4}$ inch long-nibbles strawberry leaves (Figure 8 ); but the all-important injury is caused by the small, white, legless grubs feeding on the roots (Figure 9), thus weakening or killing the plants. (See also "Black Vine Weevil".)

This species usually overwinters in the soil as half-grown larvae among the roots of the plants. In the spring the larvae form earthen cells and change 
to pupae. They remain as pupae for about 3 weeks and then develop into adults during early June, when the British Sovereign strawberry commences to ripen. After feeding for about 2 weeks they begin to lay their eggs on the ground near the crowns of the plants. The eggs usually hatch in about 10 days. The young larvae, on hatching, burrow into the soil to a depth of 6 to 10 inches and feed on the fibrous roots.
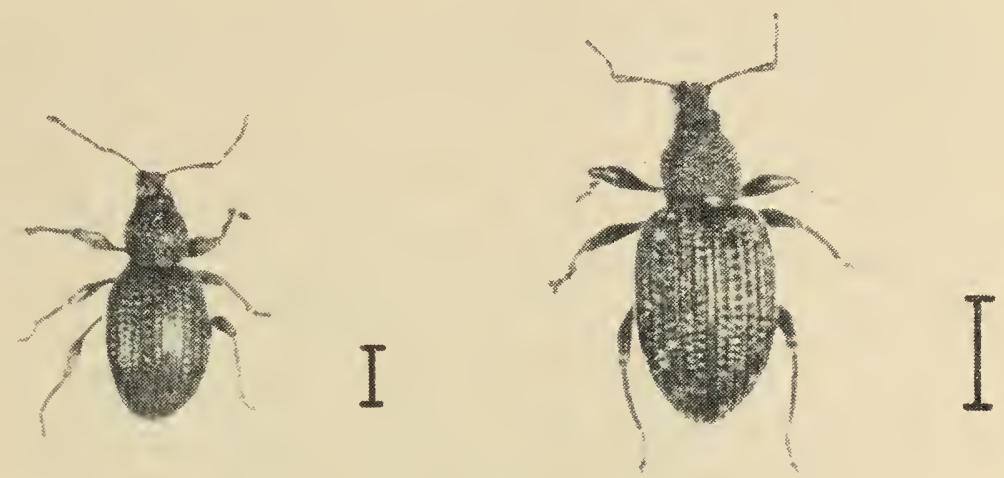

Figure 7.-Adults of the black vine weevil (right) and the strawberry root weevil (left). Length of line indicates actual size.

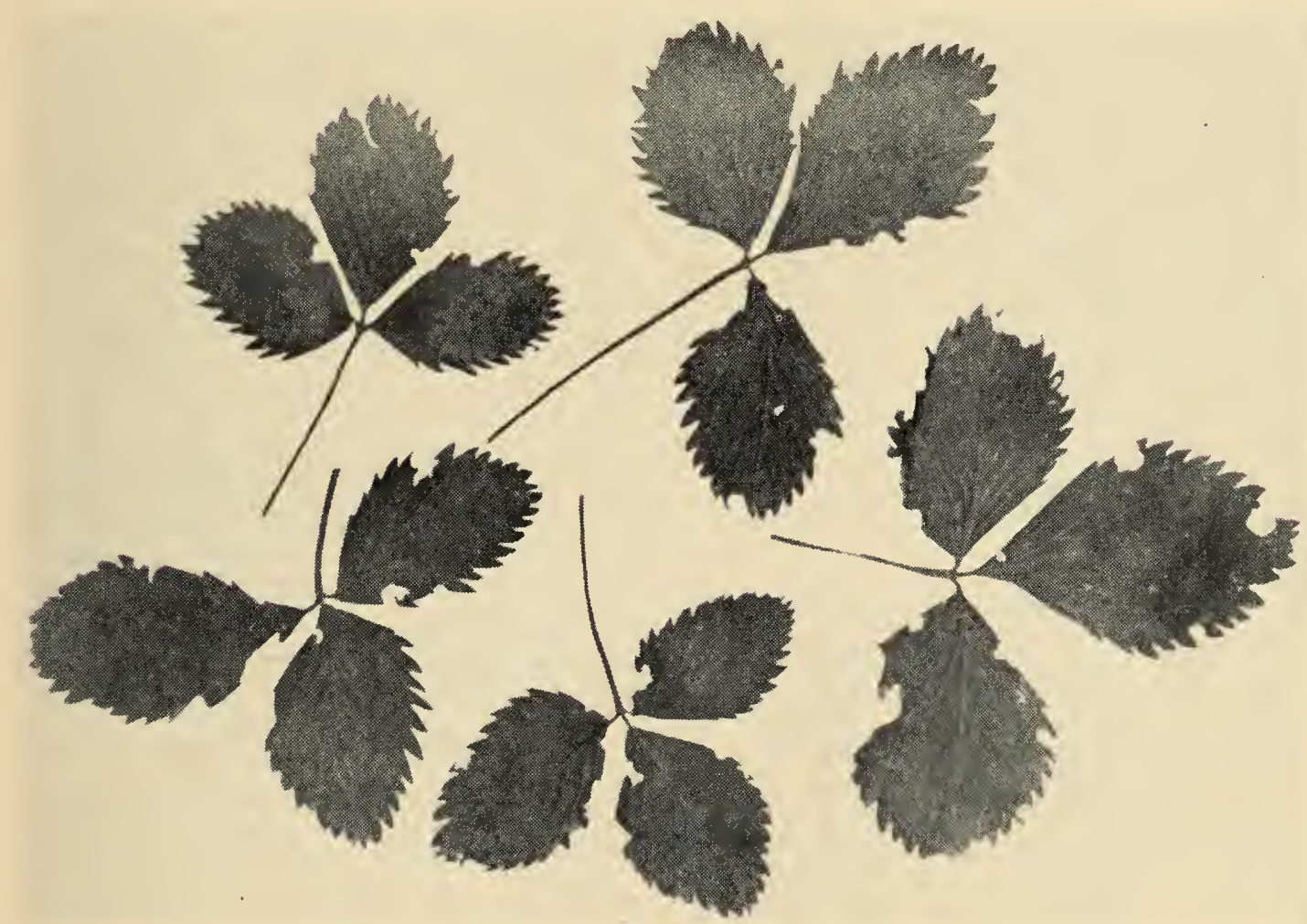

Figure 8.-Strawberry leaves attacked by adults of the strawberry root weevil.

A small percentage of these root weevils spend the winter as adults in the soil. They usually emerge about mid-April to continue laying eggs during May and June. 


\section{Control}

Weevil injury may be greatly lessened by setting out new plantings as far as possible from old ones; by planting strawberries after a non-host crop such as potatoes, mangels, or similar hoed crops; and by avoiding planting after grass or clover sod. Where the plantation has become infested, satisfactory control may be obtained only by the use of a poisoned bait.

Apply baits to kill the strawberry root weevil adults before they lay their eggs; and when an infestation is severe it is advisable to apply them twice, once about mid-April to kill the overwintering adults and again during June, when the overwintering larvae develop into adults. The June treatment is the main

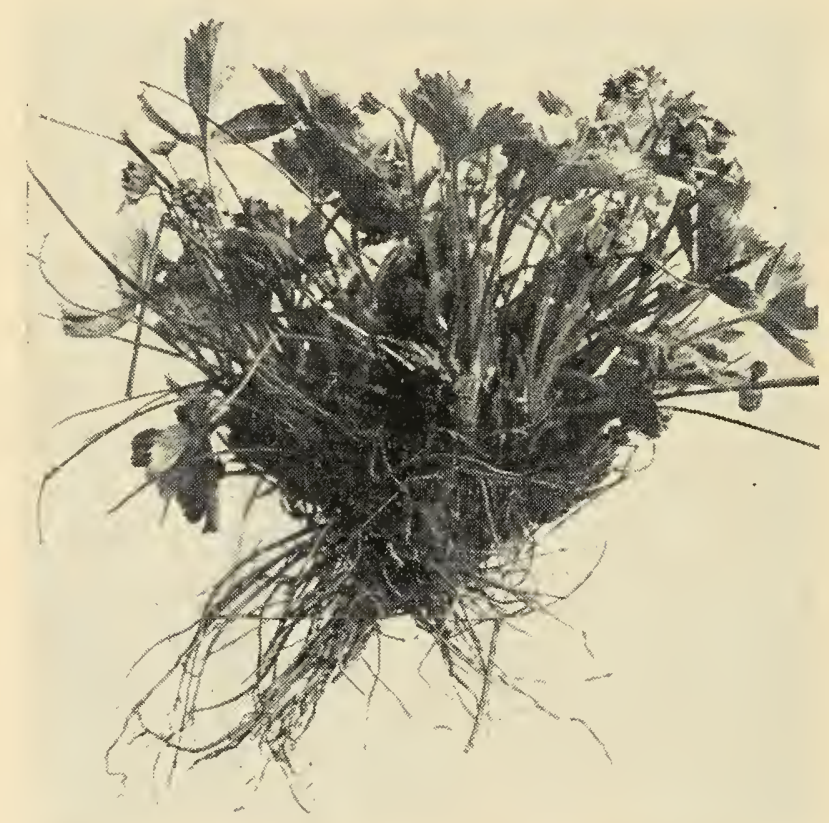

Figure 9.-Strawberry plant showing result of attack by grubs or the strawberry root weevil.

poisoning operation and, if poisoned bait is to be used at all, should not be delayed. Proper timing, which is essential to ensure good results, may be accomplished as follows:-

(1) Mid-April: Examine the leaves frequently for the ragged-edge effect resulting from the beetles' feeding on them. When "ragging" is observed (adults can be found in the soil at the bases of the plants at this time), apply the bait.

(2) June 10 to 30: Examine the soil about the crowns of the plants for presence of adult beetles. When "ragging" of the leaves is observed, apply the bait. Very often holes eaten in the ripe fruits by the beetles can also be seen at this time.

Closely examine plants bordering on old plantings, fence rows, or sod land where weevils are abundant. Locate heavily infested areas early and bait them to prevent the spread of weevils to the remainder of the crop field.

Apply one tablespoon of bait per plant (hill system), taking care that the mixture falls to the ground close to the crown rather than on growing foliage or tender stems. Make the application during dry, warm weather if possible. Use about 80 to $100 \mathrm{lb}$. of bait to treat 1 acre. 
1. Baits.-Proprietary baits consisting of ground apple waste and sodium fluosilicate have given satisfactory results in British Columbia. Do not apply them too dry; add water to moisten if necessary. If you prefer to mix your own bait, use the following formula:-

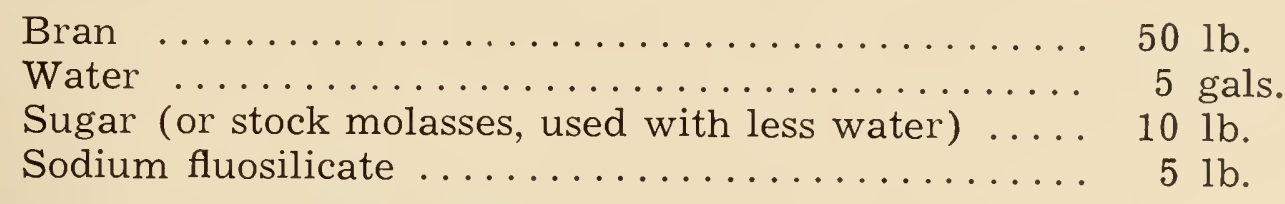

Dissolve the sugar in water; then mix the solution with the bran until it is uniformly moistened; add the poison and thoroughly mix again. Use the bait within a day or two after mixing or it will mold and lose its effectiveness.

2. Soil and Plant Treatments before Planting.-Where white grubs, the black vine weevil, or wireworms are also a problem, apply aldrin, dieldrin, chlordane, or heptachlor to the soil and to the roots of the plants before planting. Any one of these insecticides controls all four insect species for at least 3 years. The methods and rates of application are the same as outlined in the section on white grubs.

\section{Black Vine Weevil \\ Brachyrhinus sulcatus (F.)}

The life-history and habits of this insect are much the same as those of the strawberry root weevil, but the black vine weevil is much larger (Figure 7) and seems to prefer heavier types of soils. During the past 3 years it has become a major problem in British Columbia, especially on farms where irrigation or sawdust mulch are being used.

The adults emerge approximately 2 weeks later than those of the strawberry root weevil and are mainly foliage feeders.

\section{Control}

Baits do not control this weevil. Damage can be greatly lessened by setting out new plantings as far from old ones as possible and by avoiding planting after grass or clover sod. Where fields are known to be infested, use the following control measures:-

1. Soil and Plant Treatments before Planting.-Where possible, apply aldrin, dieldrin, chlordane, or heptachlor to the soil and to the roots of the plants, before planting. The methods and rates of application are the same as for white grubs. For details refer to page 12 .

2. Plant Treatments after Planting.-If the soil or the plant roots are not treated, dust or spray the foliage of the plants three times each year with aldrin, heptachlor, or chlordane. Make the first application in late April before blossoming, the second in early July (immediately after strawberry picking is completed), and the third 3 weeks later. It is most important to make an application in early July, when the overwintering grubs have developed into adults and before egg-laying has started. Dust with either $2 \frac{1}{2}$ per cent aldrin or heptachlor, or 5 per cent chlordane, using about 25 pounds per application per acre of strawberries, or a quarter of a pound per 100 plants. The most suitable equipment for applying these materials to row crops such as strawberries is a duster of the bellows or puff type.

Sprays applied to the foliage should contain 1 quart of 24 per cent aldrin or heptachlor or 1 pint of 65 per cent chlordane per 100 gallons. Apply about 200 gallons of spray per acre of strawberries each time. 
When handling these chemicals wear an approved respirator and rubber gloves. Under no circumstances dust or spray an edible crop such as strawberries with aldrin, heptachlor, or chlordane after the fruit has formed.

For further information see "Control of Root Weevils in British Columbia", Processed Publication Series, Entomology, No. 78, Canada Department of Agriculture, Ottawa.

\section{Wireworms}

Of the various species, the one that most commonly causes damage to strawberries in British Columbia is the Puget Sound wireworm, Ctenicera aeripennis aeripennis (Kby.) Figure 10. The adults are commonly called click beetles and their life-history is similar to that of white grubs. Damage usually

Figure 10.-Wireworms are yellowish-brown, shiny, slender, hard-bodied 'worms' with three pairs of short legs. When full-grown, many species are about an inch long and as thick as a match stick.

results when strawberries are planted after sod. Excellent control of wireworms has been obtained by applying aldrin, dieldrin, heptachlor, or chlordane, as recommended for the control of white grubs and root weevils. In the East, however, no control measures have been necessary to date beyond that of avoiding the planting of strawberries on land that was weedy or in sod the previous year.

\section{Strawberry Crown Moth \\ Ramosia bibionipennis (Bdvl.)}

The adults are clear-winged moths resembling small yellowjackets (Fig. 12). They can be found resting on the foliage, or flying close to the ground. The full-grown larva is about $\frac{3}{4}$ inch long, with a dark-brown head and white body. However, when the larva is half-grown the abdomen assumes a pink color, as a result of eating root tissue.

The adult moths commence to emerge from the strawberry crowns about mid-July. Eggs are laid singly on the undersides of old or new leaves next the crown. As the eggs hatch, the larvae enter the crown, where they 
tunnel within the tissue for the remainder of the summer (Fig. 11). They over-winter as nearly full-grown larvae and commence feeding again in the spring. When mature the larva develops a silken cocoon, which protrudes slightly outside of the crown of the plant at soil level. From the pupa enclosed in the cocoon, the adult emerges and the one-generation cycle is repeated.
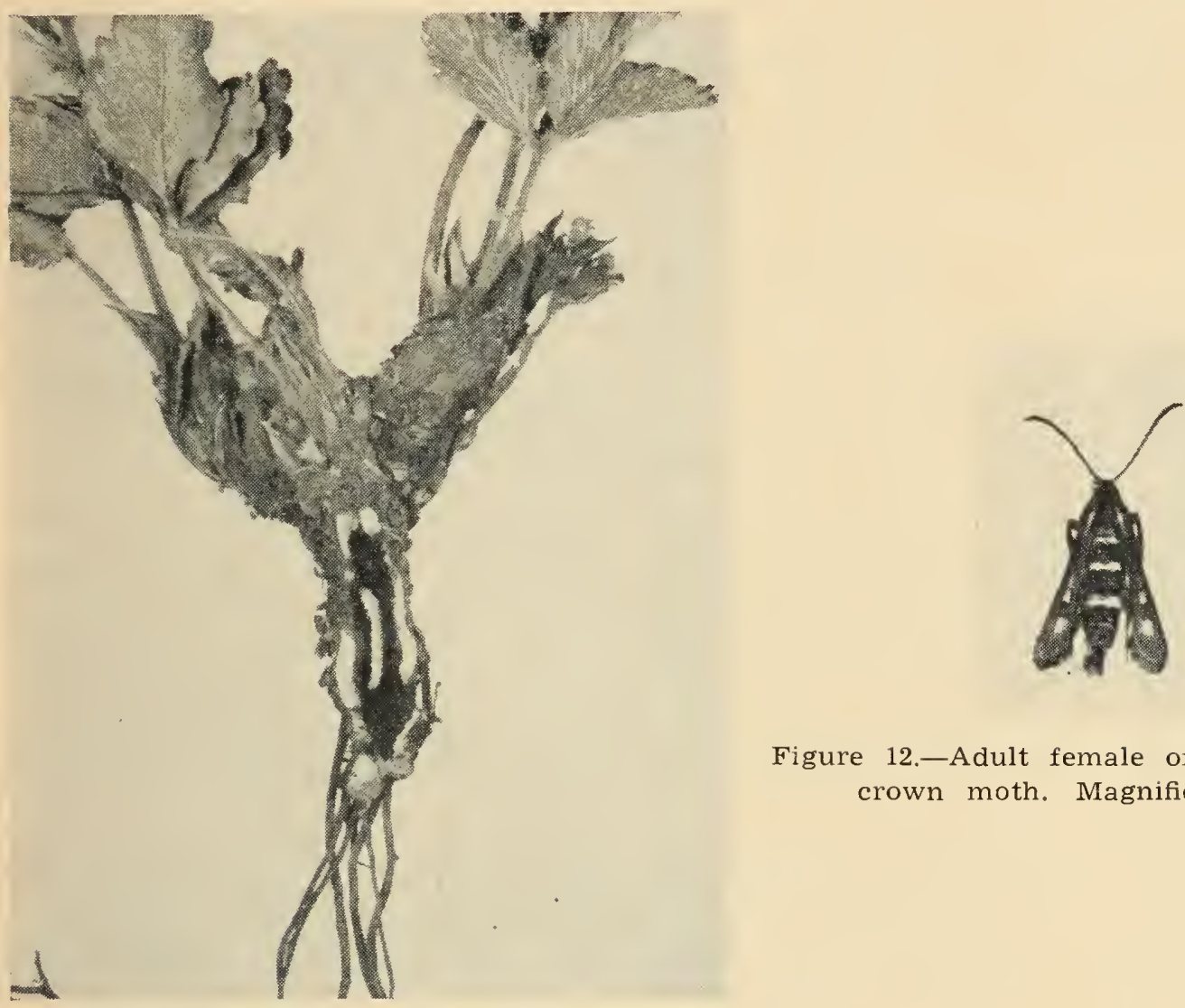

Figure 12.-Adult female of the strawberry crown moth. Magnification $1 \frac{1}{2} \times$.

Figure 11.-Larva of the strawberry crown moth and damage caused to the crown of the plant. Natural size.

\section{Control}

Remove and burn infested plants in the spring, before the moths emerge. Burn or mow the tops after strawberry harvest.

\section{Strawberry Chlamys \\ Chlamisus fragariae Brown}

This species, a new pest recently found in southwestern New Brunswick, is capable of causing severe defoliation of strawberry plantations. Although the adults feed freely in the spring and fall, the most serious damage is done by the larvae, which feed voraciously on the leaves and commonly attack the ripening fruit.

The adult is a shiny bronze beetle, cubical in shape, about $\frac{1}{4}$ inch long. The rose-colored larvae are enclosed in a black dome-shaped case, resembling the burnt head of a match. When the grubs feed, only their mouth parts and thoracic legs protrude from the case. 
Eggs on tiny stalks and covered with a protective case of excrement are laid singly on the undersides of the leaves during late May and early June. The eggs hatch in about 12 days and the larvae feed until the end of July and then pupate. Adults emerge from mid-August till the end of September and are active in the plantation until cold weather forces them into hibernation.

\section{Control}

A pre-blossom application of 3 per cent DDT dust at 40 pounds per acre provides effective control. A second application after picking time is recommended, particularly on new plantings.

\section{Strawberry Crown Miner \\ Aristotelia fragariae Busck}

This insect is established in the coastal areas of British Columbia and in Ontario. The small, carmine pink larvae bore into the crown, causing severe stunting and usually complete destruction of the plant.

The mature larvae overwinter in silken cases in the strawberry crowns. Pupae develop early in the spring and the small gray moths emerge during mid-June. Eggs are laid during the latter part of June and early July. Most of the eggs hatch during mid-July or immediately after picking has been completed. The newly emerged larvae wander over the leaf surfaces a short time before they bore into the crown just below the bases of the leaves. Feeding continues throughout the summer until the larvae reach maturity in September.

The strawberry crown miner is rarely troublesome where a short rotation is followed and new plantings are set some distance from old ones. Chemical control experiments conducted in Iowa, U.S.A., indicate that 5 per cent DDT dust applied immediately after harvest (July 15) gave good control of this species.

\section{An Aphid}

\section{Myzus ascalonicus Doncaster}

In 1955 an aphid, known in Great Britain as the shallot aphid, was recorded as a pest of strawberries for the first time in North America. It caused serious losses on several farms in southern Vancouver Island and the lower Fraser Valley, B.C.

This aphid is pale greenish brown in color and feeds on the young leaves and blossom trusses as soon as they develop from the crown. Attacked plants are dwarfed, with crinkled or curled leaves and blossoms. When the aphids are numerous this serious damage can be seen from mid-April to early May. Injury is most severe after a mild winter and spring. It is first noticed on small, circular patches of plants, and gradually spreads until the entire planting is affected.

In late May or early June, all the newly developing aphids have wings and migrate to unknown hosts. During October, winged aphids return to the strawberry plants and deposit living young that do not develop wings. Throughout the autumn, winter, and early spring, all the aphids produced are wingless. 


\section{Control}

Examine the strawberry planting during mid-April for signs of leaf curling and aphids feeding on the undersides of the new leaves. Spray twice at two-week intervals, commencing during the third week of April, with 50 per cent malathion emulsifiable concentrate at 2 pints per 100 gallons of water. For best results use 200 pounds' pressure per square inch and 3 nozzles per row. 



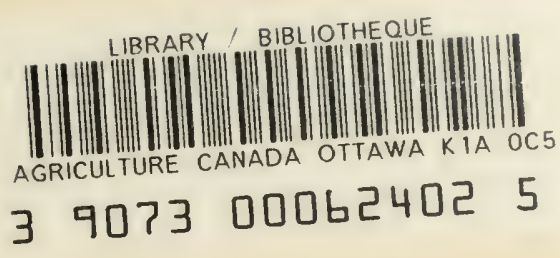


EDMOND CLOUTIER, C.M.G., O.A., D.S.P.

QUEEN'S PRINTER AND CONTROLLER OF STATIONERY OTTAWA, 1956

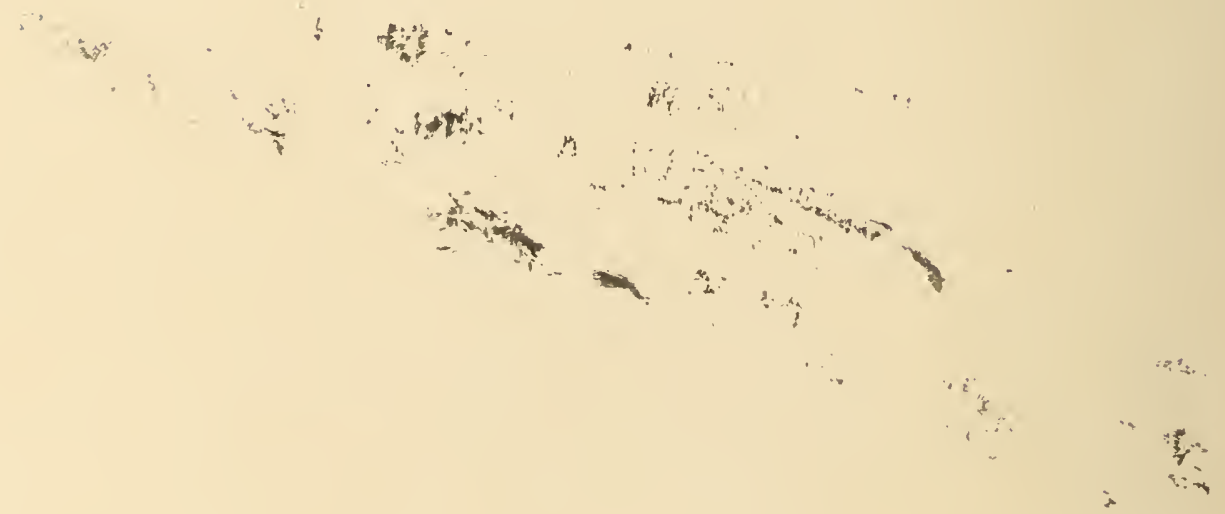

